"A monoclonal antibody that specifically recognizes $\mathrm{m}^{6} \mathrm{~A}$ nucleoside" Espuny, R., Castro, A., Codony, C., Eritja, R., Bach-Elias, M. Nucleosides \& Nucleotides, 17(12), 2189-2197 (1998). doi: 10.1080/07328319808004309

\title{
A MONOCLONAL ANTIBODY THAT SPECIFICALLY RECOGNIZES m6A NUCLEOSIDE
}

\author{
Ruth Espuny, Anna Castro, Carles Codony, Ramon Eritja\# and Montserrat \\ Bach-Elias*
}

*CID-CSIC. c/Jorge Girona Salgado 18-26 08034 Barcelona, Spain. Email: mbebmc@cid.csic.es. " present address: EMBL. Meyerhofstrasse 1. Postfach 10.2209. Heidelberg, Germany.

Abstract: A hybridoma against the nucleoside $\mathrm{m}^{6} \mathrm{~A}$ has been obtained from mouse spleen. This hybridoma was named $\mathrm{H} 65$ and it secretes monoclonal antibodies anti- ${ }^{6} \mathrm{~A}$. The competition assays showed that the monoclonal antibody was highly specific for $\mathrm{m}^{6} \mathrm{~A}$ nucleoside.

Modified nucleosides are a common feature of RNA molecules (for a review see ref. 1). In some cases, these modified nucleosides are characteristic of some RNA molecules and they have been used to classify the RNAs. One example is the nucleoside trimethylguanosine, which is a hallmark of UsnRNAs (1).

Specific nucleosides are modified post-transcriptionally, but in many cases little is known about the enzymes and the sequences or structural requirements for the modification of a specific nucleoside. $N^{6}-$ methyladenosine $\left(m^{6} A\right)$ is present at internal positions of tRNA, rRNA, mRNA and snRNA molecules (1). The consensus sequence $\mathrm{Pu}(\mathrm{G} / \mathrm{A}) \mathrm{AC}(\mathrm{U} / \mathrm{A})$ A being methylated- in the pre-mRNAs has been described as the recognition site for the methyltransferase (2). In each pre-mRNA molecule, one in every three adenosines are usually methylated (2-5). Recently, using a rabbit reticulocyte translation system it has been shown that internal $m^{6} \mathrm{~A}$ increases the in vitro translation efficiency of dihydrofolate reductase messenger RNA (6). The human $N^{6}$-Adenosine Methyltransferase of the premRNA substrate has been partially purified (7) and it consists of at least three subunits of 30,200 and $875 \mathrm{kDa}$. By further purification of the fraction containing the $200 \mathrm{kDa}$ unit, a $70 \mathrm{kDa}$ protein has been isolated, which when sequenced turned out to be a subunit of the human $N^{6}$ Adenosine Methyltransferase (8). Little is known about whether the same methyltransferase methylates all RNAs or there are specific methyltransferases for each class of RNAs. The methylated sequences found in the snRNA, tRNA and rRNA molecules are not similar to those in the mRNAs (9-11). Furthermore, the enzyme that methylates the adenosine in the U6snRNA is different to the mRNA-methyltransferase (11). 


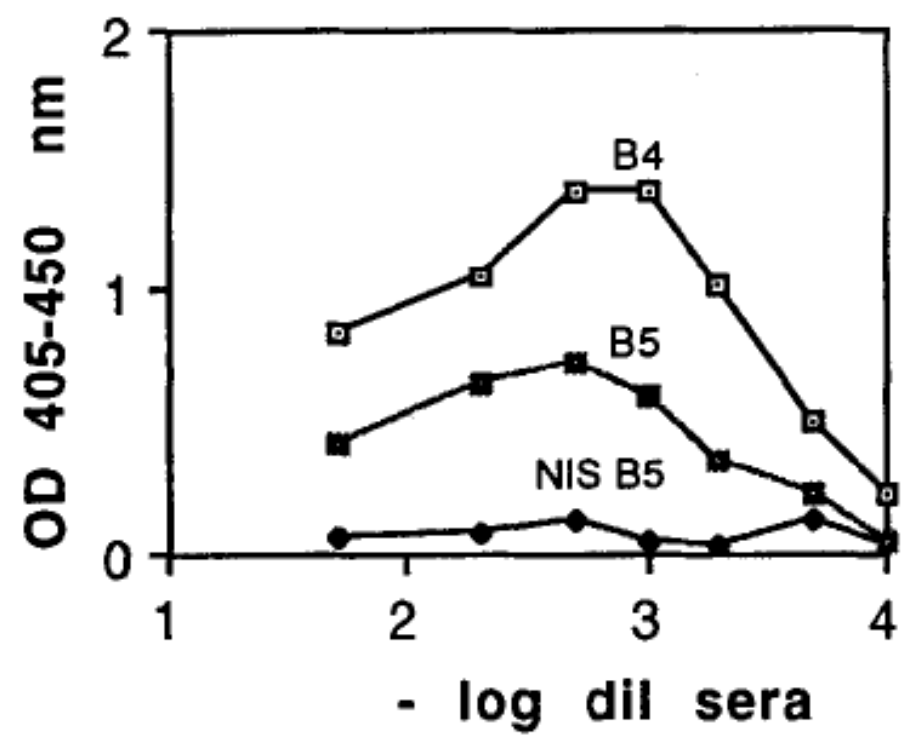

FIG. 1. Immune response of the mice to $\mathrm{m}^{6} \mathrm{~A}$ nucleoside conjugated to BSA. Two Balb/C mice (referred as B4 and B5 in the figure) were immunized with $\mathrm{m}^{6} \mathrm{~A}-\mathrm{BSA}$ following Bochning et al. (13). Twenty days after the first immunization, some blood was taken from the mouse tail and sera obtained by centrifugation of the blood. Sera from each animal was diluted 1/50 to $1 / 10000$ in PBS/T and analyzed by ELISA plates coated with $\mathrm{m}^{6} \mathrm{~A}-\mathrm{KLH}$. Preimmune sera (referred as NIS in the figure) from each animal was also diluted and analyzed in parallel. Only the OD values obtained with 85 preimmune serum are indicated in the figure. B4 and B5 serum showed a titer of around $1 / 8000$ and $1 / 6000$, respectively.

The recognition of the adenosine methylation by such a biological tool as an antibody, which is able to distinguish both between methylated and nonmethylated adenosine, and between methylation in different ring positions of nucleosidednucleotides or even hypermethylation, is an important tool to characterize this post-transcriptional mechanism. Polyclonal antibodies antim ${ }^{6} \mathrm{~A}$ that recognize the $\mathrm{m}^{6} \mathrm{~A}$ of UsnRNAs have been described (12). Here we describe a monoclonal antibody anti-msA that specifically recognizes m6A.

Two Balb/c mice (referred as B4 and B5) were immunized with the $\mathrm{m}^{6} \mathrm{~A}-\mathrm{BSA}$ conjugate as described by Bochning et al. 1987. Fig. 1 shows the titers obtained with the sera from both mice 20 days after the initial injection and coating the ELISA-wells with the $\mathrm{m}^{6} \mathrm{~A}-\mathrm{KLH}$ conjugate.

The figure also shows the results obtained with the non-immune sera (sera obtained from each mice before immunization). Sera from B4 and B5 showed titers of 118000 and 116000 , respectively. The reaction of the sera with the $\mathrm{m}^{6} \mathrm{~A}-\mathrm{KLH}$ conjugate was inhibited when the diluted sera was competed with free $\mathrm{m}^{6} \mathrm{~A}$ nucleoside (result not shown). This suggests that both animals produce antibodies specific for $\mathrm{m} 6 \mathrm{~A}$, and that they also have serum titers high enough to try to obtain a hybridoma from their $B$ lymphocytes.

Spleenocytes from B4 mouse (B5 mouse died a few days before the fusion experiment) were fused with NS1 myeloma cells. Fourteen days after 
the hybridoma fusion, the supernatants of the hybridomas were screened with $\mathrm{m}^{6} \mathrm{~A}-\mathrm{KLH}$ conjugate and 24 positive wells were selected. Out of these clones, only 13 remained stable and reacted with the $\mathrm{m}^{6} \mathrm{~A}-\mathrm{KLH}$ conjugate. Three of these hybridomas were cloned three times by limiting dilution, and one stably hybridoma was expanded and referred to as $\mathrm{H} 65$. H65 hybridoma stable secretes monoclonal antibodies (IgG1, $\kappa$ ) anti-m ${ }^{6} \mathrm{~A}$ after freezing and defrosting procedures. The reaction of the $\mathrm{H} 65$ monoclonal antibody with the $\mathrm{m} 6 \mathrm{~A}-\mathrm{KLH}$ conjugate is inhibited using free $\mathrm{m}^{6} \mathrm{~A}$ nucleoside.

Figure 2 shows that the inhibition of the reaction increases when larger amounts of free $\mathrm{m}^{6} \mathrm{~A}$ nucleoside were added to the solution, thus indicating that the antibody specifically recognizes the ${ }^{6}{ }^{6} \mathrm{~A}$ nucleoside of the conjugate. Cross-reactions with other nucleosides/ nucleotides were studied by competitive ELISA assays with the following nucleosides/ nucleotides: $\mathrm{m}^{6} \mathrm{~A} \quad\left(\mathrm{~N}^{6}\right.$-methyladenosine); A (adenosine); $\mathrm{m}_{2}{ }^{6,6} \mathrm{~A} \quad\left(\mathrm{~N}^{6}, \mathrm{~N}^{6}-\right.$ dimethyladenosine); $\quad \mathrm{m}^{1} \mathrm{~A} \quad$ (1-methyladenosine); Am (2'-Omethyladenosine); $\mathrm{m}^{6}$ Ade $\left(\mathrm{N}^{6}\right.$-methyladenine); $\mathrm{m}^{7} \mathrm{G}$ (7-methylguanosine), ATP and GTP (also showed in Figure 2). Only $\mathrm{m}^{6} \mathrm{~A}$ resulted in an inhibitory effect at a concentration of $0.01-50$ nmols (figure 2 ); whereas $\mathrm{m}^{6}$ Ade showed a very low inhibitory effect $(10 \%)$ with highest concentration of the inhibitor (50 nmols). All the other competitors studied did not inhibit the binding of the antibody to the $\mathrm{m}^{6} \mathrm{~A}-\mathrm{KLH}$ conjugate.

This property of the $\mathrm{H} 65$ monoclonal antibody distinguishes itself from the rabbit polyclonal antibody R1280 obtained in 1987 (12). R1280 significantly cross-reacted with Am (12) whereas H65 monoclonal antibody specifically recognizes 6-monomethyladenosine, since neither adenosine $(A)$ nor $\mathrm{N}^{6}, \mathrm{~N}^{6}$-dimethyladenosine $\left(\mathrm{m}_{2}{ }^{6,6} \mathrm{~A}\right)$ inhibited the reaction between the monoclonal antibody and the $\mathrm{m}^{6} \mathrm{~A}-\mathrm{KLH}$ conjugate. This second property also makes $\mathrm{H} 65$ different to R1280, as this polyclonal antibody clearly crossreacted with both $\mathrm{m}^{6} \mathrm{Ade}$ and $\mathrm{m}_{2}{ }^{6,6} \mathrm{~A}$ nucleosides (12).

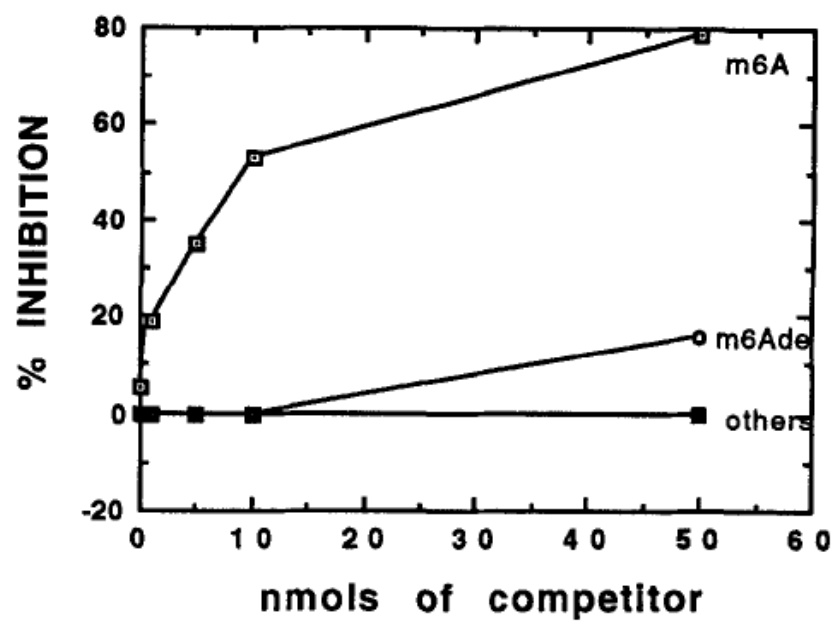

FIG. 2. The specificity of the monoclonal $\mathrm{H} 65$ antibody was showed by competition ELISA assay with $m^{6} A, m_{2}{ }^{6,6} A, m^{1} A, A m, m^{6} A d e, m^{7} G$ nucleosides and with the ATP, GTP nucleotides. The ELISA plates were coated with $\mathrm{m}^{6} \mathrm{~A}-\mathrm{KLH}$ at a concentration of $13 \mu \mathrm{g} / \mathrm{ml}$, which was maintained in all the competition assays. $100 \mu \mathrm{l}$ of the $\mathrm{H} 65$ hybridoma supernatant was mixed with increasing amount $(0,0.01$, $0.1,0.5,1,5,10$ to 50 nmols in $10 \mu \mathrm{l}$ of PBS buffer) of each 
nucleoside. A control reaction with no nucleoside was also performed ( 0 nmols in the figure). The percentage of inhibition was calculated comparing the OD values for each reaction with that obtained with 0 nmols of free nucleoside. An inhibition of around $70 \%$ was obtained with 35 nmols of free nucleoside $\mathrm{m}^{6} \mathrm{~A}$, and $10 \%$ of inhibition with 50 nmols of the nucleoside $\mathrm{m}^{6}$ Ade. Other nucleosides/nucleotides did not inhibit the antibody reaction in this range of concentrations and they are all plotted together in the line marked as "others".

In summary, adenosines methylated at different ring or ribose positions showed a higher rate of competition with the reaction of R1280 and $\mathrm{m}^{6} \mathrm{Aconjugate}$ than with that of $\mathrm{H65}$ and the conjugate.

The specificity of the $\mathrm{H} 65$ monoclonal antibody was further studied by binding assays with a nucleoside column. The nucleoside column was prepared by covalent binding of the m6A nucleoside ribose to the amino groups of EAH Sepharose 4B resin (13). This method avoided the presence of the carrier proteins (either BSA or $\mathrm{KLH}$ ) during the binding of the $\mathrm{H} 65$ monoclonal antibody to $\mathrm{m}^{6} \mathrm{~A}$ nucleoside. $\mathrm{H} 65$ monoclonal antibodies from either hybridoma supernatant or ascite fluids clearly bound to $m^{6} \mathrm{~A}-\mathrm{EAH}$ Sepharose 4B resin and bound monoclonal antibodies were then eluted by competition with free $\mathrm{m}^{6} \mathrm{~A}$ nucleoside (Figure 3 ).

This result again indicates that the binding is specific and independent of the carrier protein conjugated to the $\mathrm{m}^{6} \mathrm{~A}$ nucleoside. The purified monoclonal antibody reacted with the $\mathrm{m}^{6} \mathrm{~A}-\mathrm{KLH}$ conjugate in ELISA plates and the reaction was inhibited by free nucleoside. The purified anti$\mathrm{m}^{6} \mathrm{~A}$ monoclonal showed the same properties than the crude antibody (both from the supernatant and the ascites fluid) when tested in competition ELISA assays (data not shown).

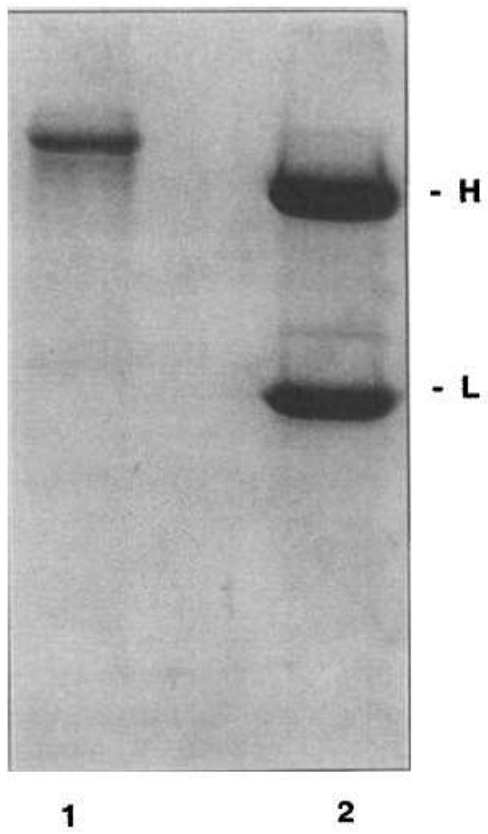

FIG. 3. The anti- $\mathrm{m}^{6} \mathrm{~A}$ nucleoside antibodies from the $\mathrm{H} 65$ hybridoma bound to $\mathrm{m}^{6} \mathrm{~A}$ nucleoside columns and were later eluted by competition with free $\mathrm{m}^{6} \mathrm{~A}$ nucleoside. Lane 1 and 2 show respectively the crude supernatant fraction of the $\mathrm{H} 65$ hybridoma before the immunoaffinity chromatography 
and the purified monoclonal antibody after loading the supernatant on the $m^{6}$ Acolumn and eluting with free $m^{6} A$ nucleoside. $H$ and $L$ mean heavy and light chains of the IgGs.

Finally, a nuclear extract from HeLa cells was immunoprecipitated with the monoclonal antibody H65. 100 p1 of hibridoma supernatant was used (corresponding to $0.2-1 \mathrm{vg}$ of antibody) in this assay. An antitrimethylguanosine monoclonal antibody $\left(\begin{array}{llll}1 & 0 & \mathrm{pg}\end{array}\right)$ that immunoprecipitates UsnRNAs, was also used as a positive control. The results obtained are shown in figure 4.

As can be seen in the figure 4, H65 immunoprecipitates both U4snRNA and a small amount of U2snRNA. Both of these UsnRNAs contain the $m^{6} A$ modification. U2snRNA is not easily immunoprecipitated with the antibody, since the $\mathrm{m}^{6} \mathrm{~A}$ modification is not very accessible to the antibody in this extract (our unpublished results). Besides the antibody did not immunoprecipitate U5snRNA (figure 4), which does not have $\mathrm{m}^{6} \mathrm{~A}$ modification. The presence of U1 snRNA in the anti- ${ }^{6} \mathrm{~A}$ immunoprecipitates has also been reported with other anti- $m^{6} \mathrm{~A}$ antibodies (12). These results indicate that our antibody recognizes the $\mathrm{m}^{6} \mathrm{~A}$ modification in RNA.

In summary, here we report a monoclonal antibody that specifically recognizes $\mathrm{m}^{6} \mathrm{~A}$ nucleoside. The antibody did not recognize either $\mathrm{A}$ or $\mathrm{m}_{2}{ }^{6,6} \mathrm{~A}$.

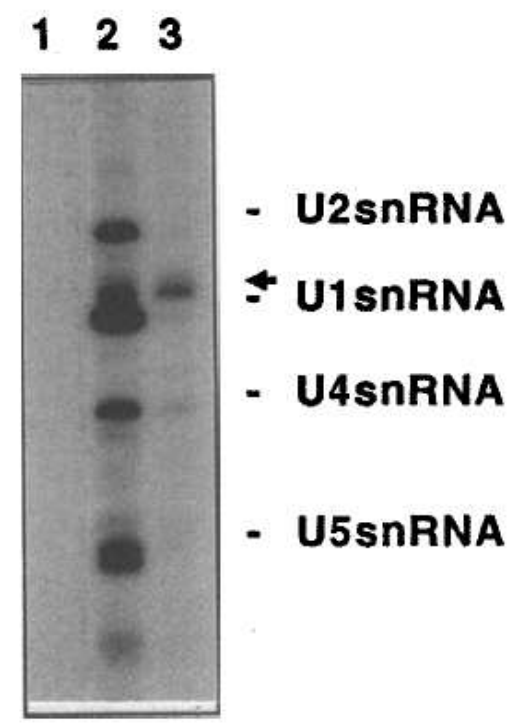

FIG. 4. Irnrnunoprecipitation of UsnRNAs with the monoclonal antibody $\mathrm{H} 65$. Lanes: 1, nonrelated monoclonal antibody (negative control); 2, monoclonal antibody Ab-1 antitrimethylguanosine (14) (10 $\mu \mathrm{g}$ of antibody) and 3, monoclonal $\mathrm{H} 65$ anti-rn ${ }^{6} \mathrm{~A}$ ( $100 \mu \mathrm{l}$ of supernatant, $0.2-1 \mu \mathrm{g}$ of antibody). The band marked with an arrowhead corresponds to $5.8 \mathrm{~S}$ ribosomal RNA and is caused by an inespecific reaction of both antibodies (antitrirnethylguanosine and anti-rm ${ }^{6} \mathrm{~A}$ ) in these conditions, and it is due to the fact that this RNA is a very good substrate for $p C p$ labeling. As $p C p$ labeling does not allow to quantify RNAs (since different RNAs are differentially labeled with this technique) the intensity of these bands does not reflect the real amount of RNA in the band. 


\section{EXPERIMENTAL SECTION}

\section{$\mathbf{m}^{6} \mathbf{A}$-Conjugates and nucleosides/nucleotides}

The nucleoside $\mathrm{m}^{6} \mathrm{~A}$ (Sigma) was conjugated either to the carrier $\mathrm{KLH}$ (keyhole limpet hemocyanin) or to BSA (bovine serum albumin) following the method described by Erlanger and Beiser (15). Other nucleosides/ nucleotides used in this work were purchased from Sigma.

\section{Mice immunization and fusions}

Two female Balb/c mice were immunized with $400 \mu \mathrm{g}$ of the $\mathrm{m}^{6} \mathrm{~A}-\mathrm{BSA}$ conjugate following the method described by Boching et al. (immunogen in complete adjuvant on day 0 , and immunogen in incomplete adjuvant on days 20, 28, 33, 34 and 35) (13). Both mice rendered good antibody titers (see Fig. 1 in results). The spleenocytes isolated from both mice on day 36 were fused to NS1 myeloma cells (13).

\section{Screening of anti-m ${ }^{6} \mathrm{~A}$ positive clones and hybridoma cloning}

14 days after the spleenocyte fusion, the supernatants were screened with ELISA plates coated with $\mathrm{m}^{6} \mathrm{~A}-\mathrm{KLH}$ conjugate. Hybridomas in positive wells were cloned by limiting dilution. One clone, referred as $\mathrm{H} 65$, remained stable after three cloning steps by limiting dilution. This clone was also stable after freezing/defrosting treatments.

\section{ELISAs with the $m^{6} A-K L H$ conjugate.}

Each ELISA well was coated with $50 \mu \mathrm{g}$ of $\mathrm{m}^{6} \mathrm{~A}-\mathrm{KLH}$ solution $(13 \mu \mathrm{g}$ $/ \mathrm{ml}$ ) in PBS (20 mM KH $\mathrm{PO}_{4} \mathrm{pH} 7.4,140 \mathrm{mM} \mathrm{NaCl}, 0.02 \% \mathrm{NaN}_{3}$ ) and incubated overnight at $4{ }^{\circ} \mathrm{C}$. On the next day, the plates were washed three times with PBS/T (PBS with $0.1 \%$ Tween 20). The wells were then incubated with the antibody solutions: either $50 \mu$ l of mice sera diluted $1 / 50$ to $1 / 10000$ in PBS/T, $100 \mu$ of hybridoma supernatants diluted $1 / 2$ in PBS/T or $100 \mu \mathrm{l}$ of non-diluted supernatants without dilution. The ELISA plates were then incubated for $90 \mathrm{~min}$ at room temperature. Then, the plates were washed three times with PBS/T and each well was incubated for $2 \mathrm{~h}$ at room temperature with $50 \mu \mathrm{l}$ of anti-mouse IgG conjugated to alkalinephosphatase and diluted $1 / 1000$ in PBS/T. The plates were washed three times with $\mathrm{PBS} / \mathrm{T}$ and incubated with the substrate solution $(50 \mathrm{mM}$ $\mathrm{Na}_{2} \mathrm{CO}_{3} / \mathrm{NaHCO}_{3} \mathrm{pH} 9.5,2 \mathrm{mM} \mathrm{MgCl} 2$ and $1 \mathrm{mg} / \mathrm{ml}$-nitrophenylphosphate). The plates were measured at $405-450 \mathrm{~nm} 30$ rnin after substrate addition.

\section{ELISA competition-assay.}

Each ELISA well was coated with $50 \mu \mathrm{l}$ of $\mathrm{m}^{6} \mathrm{~A}-\mathrm{KLH}$ solution $(13 \mu \mathrm{g}$ $/ \mathrm{ml}$ ) in PBS (20 mM KH $\mathrm{KH}_{4} \mathrm{pH} 7.4,140 \mathrm{mM} \mathrm{NaCl}, 0.02 \% \mathrm{NaN}_{3}$ ) and incubated overnight at $4{ }^{\circ} \mathrm{C}$. On the next day, the plates were washed three times with PBS/T. Wells were saturated with a solution containing $0.5 \%$ teleostean gelatin in PBS for $1 \mathrm{~h}$ at room temperature. The competition solution was prepared as follows: $100 \mu \mathrm{l}$ of the hybridoma supernatant was incubated with different amounts of each nucleoside (from 0 to 50 nmols, each quantity dissolved in $10 \mu \mathrm{l}$ of PBS), in different tubes for $1 \mathrm{~h}$ at room temperature. After saturation, the ELISA wells were washed three times with $\mathrm{PBS} / \mathrm{T}$. Each well was then incubated with one of the competition 
solutions $(110 \mu \mathrm{l})$ for $1 \mathrm{~h}$ at room temperature. From this point, the ELISA plates were treated as described above.

\section{Immunoprecipitation assay.}

Immunoprecipitation assay was performed as previously described (16). pCp labeling of the UsnRNAs was performed as indicated in the previous publication (16).

\section{ACKNOWLEDGEMENTS}

We thank J.M. Barrios for technical assistance, and all members of the M. Bach-Elias' group for the comments about the manuscript. This work was supported by PGC grant no PB92-0004. C. Codony was recipient of a fellowship from PGC.

\section{REFERENCES}

1 .Limbach, P. A., Crain, P. F. and Mccloskey, J. A. Nucleic Acids Res., 1994, 22, 2183.

2. Schibler, U., Kelley, D. E. and Perry, R. P. J. Mol. Biol., 1977, 115, 695.

3. Wei, C. M. and Moss, B. Biochemistry, 1977, 16, 1672.

4. Desrosiers, R. C., Friderici, K. H. and Rottman, F. M. Biochemistry, 1975, $74,4367$.

5. Lavi, U., Fernandez-Munoz, R. and Darnell, J. E. J. Nucleic Acids Res., 1977, 4, 63.

6. Heilman, K. L., Leach, R. A. and Tuck, M. T. Int. J. Biochem. Cell. Biol., 1996, 28, 823.

7. Bokar, J. A., Rath-Shambaugh, M. E., Ludwiczak, R., Narayan, P. and Rottman, F. J. Biol. Chem., 1994, 269, 17697.

8. Bokar, J. A., Shambaugh, M. E., Polayes, D., Matera, A. G. and Rottman, F. M. RNA, 1997, 3, 1233.

9. Bjork, G. R., Ericson, J. U., Gustafsson, C. E. D., Hagervall, T. G., Jonsson, Y. H. and Wikstrom, P. M. Annu. Rev. Biochem., 1987, 56, 263.

10. Maden, B. E. H. Prog. Nucleic Acid Res. Mol. Biol., 1990, 39, 241.

11. Shimba, S., Bokar, J. A., Rottman, F. and Reddy, R. Nucleic Acids Research, 1995, 23, 2421.

12. Bringmann, P. and Lührmann, R. FEBS Lett.,1987, 213, 309.

13. Bochnig, P., Reuter, R., Bringmann, P. and Lührmann, R. Eur. J. Biochem., 1987, 168, 461.

14. Krainer, A. R. Nucleic Acids Res., 1988, 16, 9415.

15. Erlanger, B. F.and Beiser, S. M. Proc. Natl. Acad, Sci. USA, 1964, 52, 68.

16. Steitz, J. RNA Processing. Part A. General Methods., 1989, 180, 468. 